\title{
Proximalized Total Arch Replacement Can Be Safely Performed by Trainee
}

\author{
Sentaro Nakanishi ${ }^{1}$ Naohiro Wakabayashi ${ }^{1}$ Hayato Ise ${ }^{1}$ Hiroto Kitahara ${ }^{1,2}$ Aina Hirofuji ${ }^{1}$ \\ Natsuya Ishikawa ${ }^{1}$ Hiroyuki Kamiya ${ }^{1}$
}

1 Department of Cardiac Surgery, Asahikawa Medical University, Midorigaoka Higashi 2-1-1-1, Asahikawa 078-8510, Japan

2 Department of Cardiac Surgery, MedStar Heart and Vascular Institute/Georgetown University School of Medicine,

Washington, DC

Thorac Cardiovasc Surg 2021;69:336-344.

\begin{abstract}
Address for correspondence Hiroyuki Kamiya, MD, Department of Cardiac Surgery, Asahikawa Medical University, Midorigaoka-Higashi, Asahikawa 078-8510, Japan (e-mail: hkamiya88@yahoo.co.jp).
\end{abstract}

\begin{abstract}
Keywords

- total arch replacement

- frozen elephant trunk

- extra-anatomical bypass

- trainee

- education

Background The aim of the present study was to validate safety of total arch replacement (TAR) using a novel frozen elephant trunk device, operated by trainees as surgical education.

Methods Sixty-four patients including 19 patients (29.6\%) with acute aortic dissection type A (AADA) underwent TAR in our institute between April 2014 and March 2019 were retrospectively analyzed. Twenty-nine patients were operated by trainees (group T) and 35 patients were operated by attending surgeons (group A).

Results Patient characteristics did not differ between groups. Operative time ( $409.4 \pm 87.8$ vs. $468.6 \pm 129.6$ minutes, $p=0.034)$, cardiopulmonary bypass time ( $177.7 \pm 50.4$ vs. $222.9 \pm 596.7$ minutes, $p=0.019$ ), and hypothermic circulatory arrest time ( $39.5 \pm 13.4$ vs. $54.5 \pm 18.5$ minutes, $p=0.001)$ were significantly shorter in group $A$ than in group $T$, but aortic clamping time did not differ between groups $(115.3 \pm 55.7$ vs. $114.2 \pm 35.0$ minutes, $p=0.924)$ because the rate of concomitant surgery was higher in group A ( 37.1 vs. $10.3 \%, p=0.014)$. Thirty-day mortality was $3.1 \%$ in the entire cohort. Although operation time was longer in group $\mathrm{T}$, there were no significant difference in postoperative results between the groups, and the experience levels of the main operator were not independent predictors for in-hospital mortality + major postoperative complications. There was no difference in late death and aortic events between groups.

Conclusions The present study demonstrated that TAR can be safely performed by trainees, and suggests TAR as a possible and safe educational operation.
\end{abstract}

\section{Introduction}

With recent improvements in surgical technique, strategic cerebral protection during cardiopulmonary bypass, evolved graft material, and expert anesthesiological management, outcomes of total arch replacement (TAR) has improved dramatically in the last decade. ${ }^{1-5}$ Nevertheless, TAR has still remained a surgical challenge. Therefore, TAR is usually performed only by very experienced surgeons in most institutes. received

March 26, 2020 accepted after revision

April 29, 2020

published online

July 7, 2020
DOI https://doi.org/ 10.1055/s-0040-1713354. ISSN 0171-6425.

\footnotetext{
(C) 2020. The Author(s).

This is an open access article published by Thieme under the terms of the Creative Commons Attribution-NonDerivative-NonCommercial-License, permitting copying and reproduction so long as the original work is given appropriate credit. Contents may not be used for commercial purposes, or adapted, remixed, transformed or built upon. (https://creativecommons.org/ licenses/by-nc-nd/4.0/) Georg Thieme Verlag KG, Rüdigerstraße 14, 70469 Stuttgart, Germany
} 
There are many reasons for why TAR is considered unsuitable for surgical education. To name a few, the diseased aortic wall is sometimes difficult to suture, the extensive number of procedural steps, long operation time, and the yet high mortality and morbidity rates. However, in our opinion, the main reason associated with why TAR is considered unsuitable for inexperienced surgeons is the very deep and narrow surgical field for the distal anastomosis. For surgical education, it is absolutely necessary that the supervising experienced surgeon share the same surgical field from the left side of the operation table as the first assistant. However, vantage of the distal anastomosis site of TAR is sometimes only available from the operating surgeon. Because of this difficult surgical field, TAR is difficult as an educational case.

Since the commercialization of a novel frozen elephant trunk (FET) device in Japan, ${ }^{6,7}$ we have been performing "proximalized" TAR, in which the standard procedure for distal anastomosis is done between the left subclavian artery and the left common carotid artery (zone 2), between the left common carotid artery and the brachiocephalic trunk (zone 1 ), or at the ascending aorta (zone 0 ). This proximalized TAR was also performed by trainees as surgical education. The aim of the present study was to validate the safety of TAR using the novel FET device (Frozenix, Lifeline Japan, Japan) when operated by trainees as surgical education.

\section{Methods}

\section{Patients}

Between April 2014 and March 2019, 87 patients underwent TAR in our institution. Among them, the novel FET was used in 64 patients and the medical records were retrospectively analyzed. Of them, 19 patients (29.6\%) were operated due to acute aortic dissection type A (AADA). Twenty-nine patients were operated on by trainees, and they were categorized in group $\mathrm{T}$; thirty-three patients were operated by attending surgeons and categorized in group A. This retrospective study was approved by the institutional review board (IRB). Written informed consent was obtained preoperatively from all patients, hereby the refusal right was warranted for all patient and it was clearly documented on the university homepage (http://www.asahikawa-med.ac.jp/).

\section{Our Definition of "Trainee"}

In the present study, surgeons having less than 100 open heart surgery experience as the first operator (operator A: 50 cases, operator B: 30 cases, operator C: 20 cases, operator D: 10 cases, and operator E: 3 cases) were defined as a trainee. On the other hand, attending surgeon A had experience of more than 2,500 open heart surgeries including more than 250 TARs, and attending surgeon B had experience in more than 500 open heart surgeries including more than 100 TARs.

\section{Indications for Proximalized Total Arch Replacement}

Since August 2015, we have performed TAR using the Frozenix FET technique as the first choice for aneurysms located in the distal aortic arch (- Figs. 1 and 2). On the other hand, in cases where the aortic aneurysm was located in the middle of the aortic arch with the largest diameter in the proximal aortic arch region, we performed a classical TAR without FET. In cases with AADA, the proximalized TAR was the choice of therapy in all patients in our institute.

\section{Patient Selection for Surgical Education}

The main operator was discussed and selected according to operative risks during our preoperative conferences. To estimate operative risk, we used JapanSCORE for all patients. JapanSCORE is an operative risk calculating system similar to EuroSCORE and STS score. JapanSCORE is calculated based on the Japan Cardiovascular Surgery Database, which is

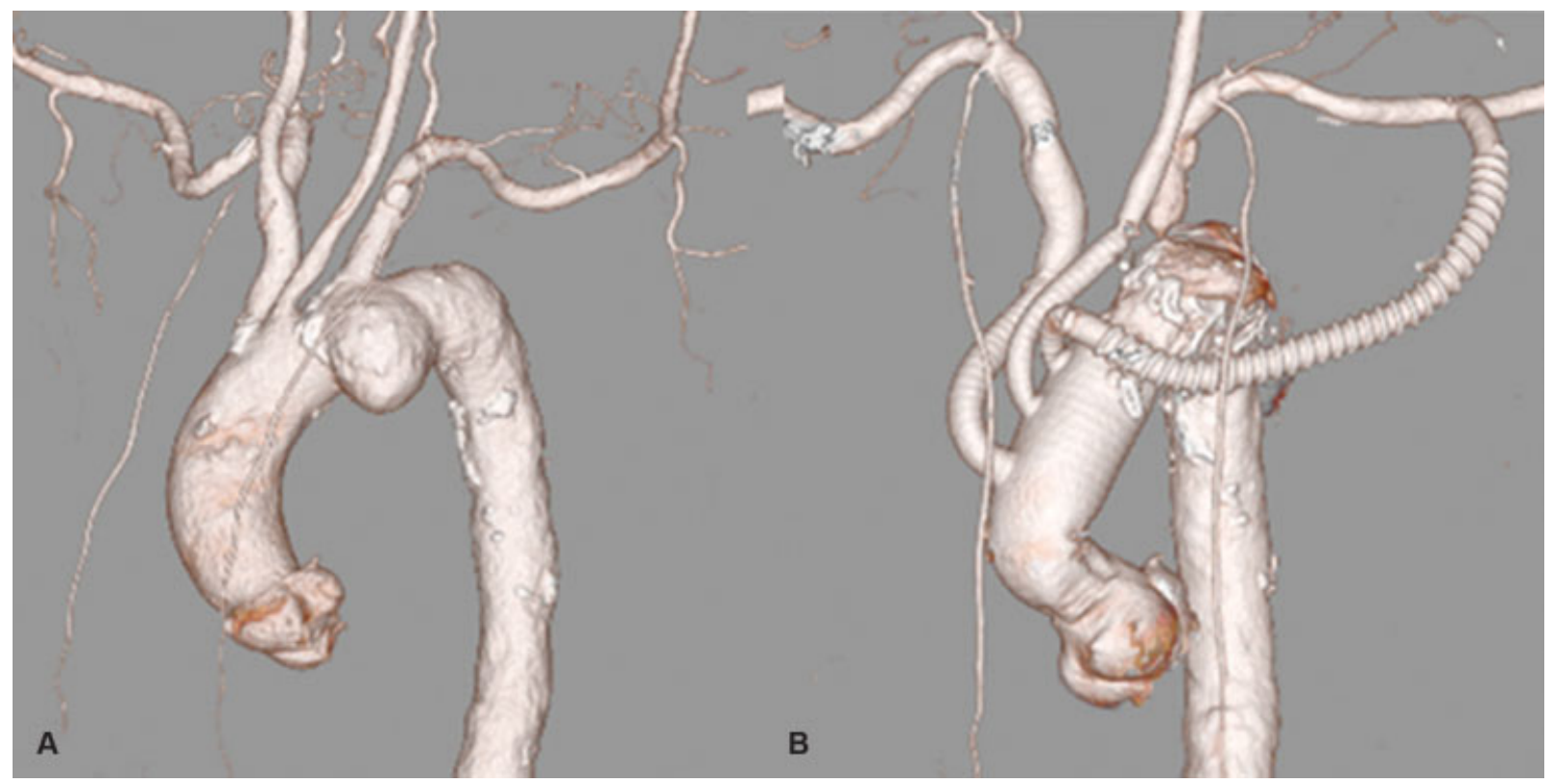

Fig. 1 (A) Saccular aneurysm of the distal aortic arch is very suitable for proximalized total arch replacement (TAR) with frozen elephant trunk (FET). (B) Postoperative CT finding. CT, computed tomography. 


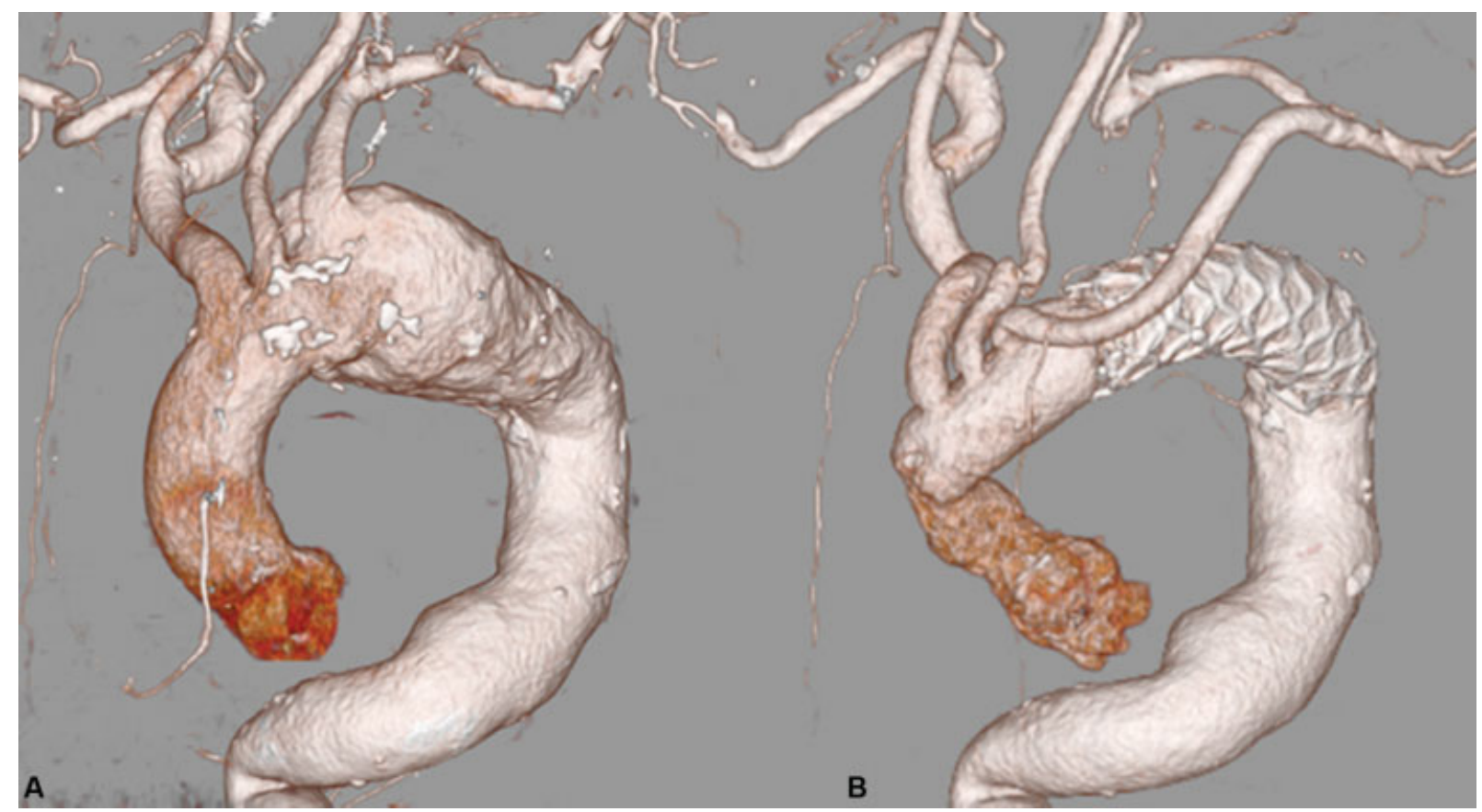

Fig. 2 (A) Fusiform aneurysm of the distal aortic arch is also suitable for proximalized TAR with FET. (B) Postoperative CT finding. CT, computed tomography; FET, frozen elephant trunk; TAR, total arch replacement.

generated from data contributed by 591 participating institutions. JapanSCORE was first established in 2008, and it is updated regularly using the Japan Cardiovascular Surgery Database. ${ }^{8}$ In addition to general risk factors (diabetes mellitus, chronic kidney disease, etc.) and quality of the aortic wall detected by computer tomography, the general activity of patients was also taken into consideration. Generally, lowrisk patient cases were assigned to trainees and high-risk patients or patients having shaggy aorta were assigned to attending surgeons. In cases of AADA, patients having dissected supra-aortic vessels were assigned to attending surgeons and only those patients who were hemodynamically stable having nondissected supra-aortic vessels were assigned to trainees.

\section{Surgical Technique}

The operation is performed in a normal supine position. At first, the left axillary artery is exposed in the facia between the deltoid muscle and the major pectoral muscle. In this position, the axillary artery does not run so deeply and it is relatively easy to expose. However, one should take care to avoid injury of the brachial plexus because the axillary artery is normally located directly behind the brachial plexus. After exposing the left axillary artery, upon sufficient heparinization, an 8-mm expanded polytetrafluoroethylene prosthesis (ePTFE; Gore Propaten; W. L. Gore \& Associates, Flagstaff, Arizona, United States) is anastomosed in an end-to-side fashion. The other end of the vessel prosthesis is then connected to one of the selective cerebral perfusion circuits. Next, the medial sternotomy is performed. Cardiopulmonary bypass ( $\mathrm{CPB}$ ) is established with arterial cannulation into the ascending aorta and bicaval venous drainage. A vent tube is inserted into the left atrium through the right upper pulmonary vein. The patient is cooled with a goal rectal temperature of $26^{\circ} \mathrm{C}$. During systemic cooling, the ascending aorta is cross-clamped and cardioplegic solution is administered. In cases of aneurysm, antegrade cardioplegia is applied from the aortic root. In cases of AADA, retrograde cardioplegia is administered to avoid manipulation of the fragile intima of the coronary arteries' ostia. The ascending aorta is then transected at a level of $1-\mathrm{cm}$ distal from the sinotubular junction. The short end of the prosthesis derived from the four-branched prosthesis is anastomosed to the proximal ascending aorta using the modified turn-up technique. After completion of the anastomosis, the anastomosis line is sealed with BioGlue (CryoLife, Northwest, United States). Thereafter, hypothermic circulatory arrest (HCA) is induced, and simultaneously, retrograde cerebral perfusion is started through the venous cannula inserted into the superior vena cava, maintaining the perfusion pressure at $15 \mathrm{~mm} \mathrm{Hg}$. Then, the aortic clamp is removed for inspection of the aortic arch. The left subclavian artery is ligated and the left common carotid artery also ligated if zone 1 anastomosis is planned. The brachiocephalic trunk is intubated from the inside of the aortic arch. The common carotid artery is intubated from the inside of the aortic arch, or cut in half and intubated from the outside. Retrograde cerebral perfusion is stopped and antegrade selective cerebral perfusion is started, hereby the brachiocephalic trunk and the left common carotid artery are perfused with cannulas and the left subclavian artery is perfused through the vascular graft anastomosed onto the left axillary artery in the beginning of the operation. Then, the aortic arch is transected. Zone 3 anastomosis is performed only if the zone 0,1 , or 2 transections are technically difficult ( - Fig. 3A-D). The FET is then inserted into the descending aorta and deployed. The diameter and length of the FET prosthesis are preoperatively determined according to 

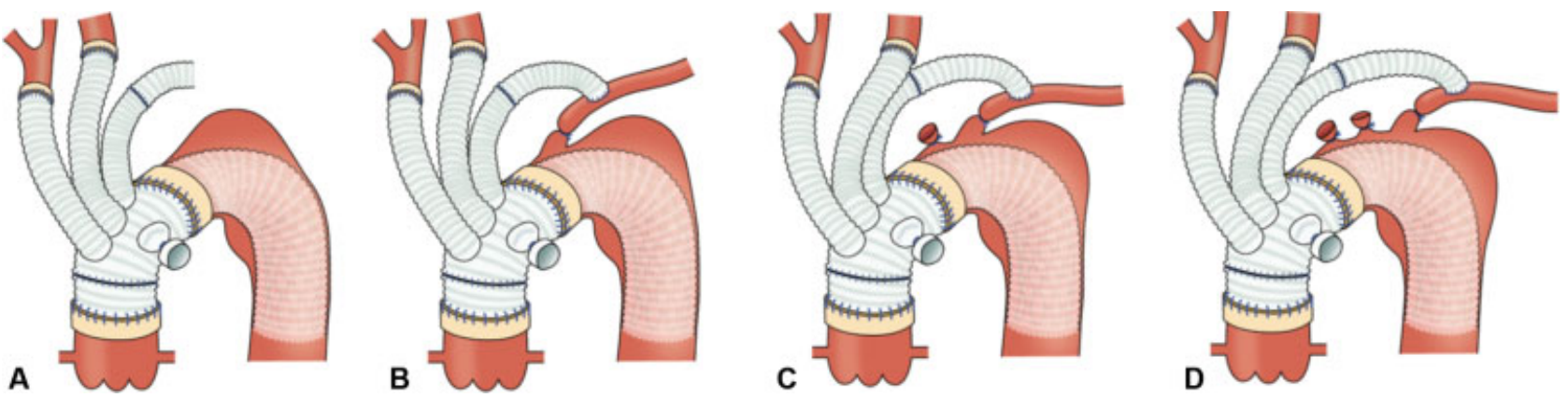

Fig. 3 (A) TAR with frozen elephant trunk with zone-3 anastomosis. All arch vessels are in-situ reconstructed. (B) Proximalized TAR with zone-2 anastomosis. The left subclavian artery is ligated. (C) Proximalized TAR with zone-1 anastomosis. The left subclavian artery and the left common carotid artery are ligated. (D) Proximalized TAR with zone-0 anastomosis. All arch vessels are ligated. TAR, total arch replacement.

computed tomography (CT) findings. After deploying of the FET prosthesis, the proximal end is trimmed, and then the fourbranched graft is anastomosed. Then a side branch of the prosthesis is connected to the arterial line of $\mathrm{CPB}$ and perfusion of the lower body is restarted. At this time, rewarming is started. Then the four-branched prosthesis and graft anastomosed to the proximal aorta are anastomosed together. Then, the aortic clamp is removed. Thereafter, the $8-\mathrm{mm}$ vessel prosthesis anastomosed to the left axillary artery is anastomosed to a side branch. Then, a side branch is anastomosed to the common carotid artery and the last side branch is anastomosed to the brachiocephalic trunk. Immediately after this last anastomosis, CPB can be weaned.

\section{Follow-up and Definition of Aortic Events}

Follow-up information on all patients was collected through planned outpatient visits in the course of regular clinical follow-ups, and the follow-up rate in the present study was $100 \%$. Aortic events were defined as distal stent-graft induced new entry (dSINE) and/or enlargement of the aneurysm. For extensive thoracic aortic aneurysms, we prefer to use a FET of $9 \mathrm{~cm}$ followed by thoracic endovascular aortic repair (TEVAR) 3 to 6 months after the initial operation to avoid spinal cord injury stemming from an excessive FET. Such cases requiring two-stage surgery were not counted as aortic events.

\section{Statistical Analysis}

Categorical variables are expressed as proportions and continuous variables as mean \pm standard deviation throughout this study. Survival and freedom from aortic events were analyzed with Kaplan-Meier actuarial methods. Variables with a univariate $p$-value of 0.2 or less, and experience of the operator (divided into group A or T), were used in the multivariate regression analysis. All statistical analyses were performed using SPSS Statistics 22.0 (IBM, Armonk, New York, United States).

\section{Results}

Patient characteristics are demonstrated in -Table 1. There were no significant differences between group $A$ and group $T$, but there was tendency for more reoperative cases in group $\mathrm{A}$
Table 1 Patient characteristics

\begin{tabular}{|l|l|l|l|}
\hline & $\begin{array}{l}\text { Group A } \\
(\boldsymbol{n}=35)\end{array}$ & $\begin{array}{l}\text { Group T } \\
(\boldsymbol{n}=\mathbf{2 9})\end{array}$ & $p$-Value \\
\hline $\begin{array}{l}\text { Age (y) } \\
\text { Mean } \pm \text { SD }\end{array}$ & $69.7 \pm 11.1$ & $72.7 \pm 9.4$ & 0.232 \\
\hline $\begin{array}{l}\text { Male } \\
n(\%)\end{array}$ & $24(68.6)$ & $19(65.5)$ & 0.796 \\
\hline $\begin{array}{l}\text { Height (cm) } \\
\text { Mean } \pm \text { SD }\end{array}$ & $160.8 \pm 9.6$ & $159.8 \pm 9.9$ & 0.701 \\
\hline $\begin{array}{l}\text { Weight (kg) } \\
\text { Mean } \pm \text { SD }\end{array}$ & $62.9 \pm 16.9$ & $62.2 \pm 17.5$ & 0.884 \\
\hline $\begin{array}{l}\text { Body mass } \\
\text { index (kg/m }) \\
\text { Mean } \pm \text { SD }\end{array}$ & $24.1 \pm 5.0$ & $24.0 \pm 5.3$ & 0.970 \\
\hline $\begin{array}{l}\text { Hypertension } \\
n(\%)\end{array}$ & $30(85.7)$ & $23(79.3)$ & 0.499 \\
\hline $\begin{array}{l}\text { Diabetes mellitus } \\
n(\%)\end{array}$ & $5(14.3)$ & $7(24.1)$ & 0.315 \\
\hline $\begin{array}{l}\text { Hyperlipidemia } \\
n(\%)\end{array}$ & $13(37.1)$ & $12(41.4)$ & 0.729 \\
\hline $\begin{array}{l}\text { Current smoker } \\
n(\%)\end{array}$ & $9(25.7)$ & $11(37.9)$ & 0.294 \\
\hline $\begin{array}{l}\text { Chronic kidney } \\
\text { disease } \\
n(\%)\end{array}$ & $5(14.3)$ & $4(13.8)$ & 0.955 \\
\hline $\begin{array}{l}\text { Serum creatinine } \\
\text { (mg/dL) } \\
\text { Mean } \pm \text { SD }\end{array}$ & $1.14 \pm 0.71$ & $0.89 \pm 0.24$ & 0.052 \\
\hline $\begin{array}{l}\text { Hemodialysis } \\
n(\%)\end{array}$ & $1(2.9)$ & $0(0)$ & 0.359 \\
\hline $\begin{array}{l}\text { Previous PCl } \\
n(\%)\end{array}$ & $2(5.7)$ & $3(10.3)$ & 0.492 \\
\hline $\begin{array}{l}\text { Acute aortic } \\
\text { dissection } \\
\text { type A } \\
n(\%)\end{array}$ & $12(34.3)$ & $7(24.1)$ & 0.376 \\
\hline $\begin{array}{l}\text { Reoperative case } \\
n(\%)\end{array}$ & $4(11.4)$ & $0(0)$ & 0.060 \\
\hline $\begin{array}{l}\text { Japan score } \\
\text { Mean } \pm \text { SD }\end{array}$ & $9.1 \pm 7.5$ & $6.9 \pm 5.3$ & 0.170 \\
\hline
\end{tabular}

Abbreviations: Group A, group of attending surgeons; Group T, group of trainees; $\mathrm{PCl}$, percutaneous coronary intervention; SD, standard deviation. 
Table 2 Operative parameter and complications

\begin{tabular}{|c|c|c|c|}
\hline & $\begin{array}{l}\text { Group A } \\
(n=35)\end{array}$ & $\begin{array}{l}\text { Group T } \\
(n=29)\end{array}$ & p-Value \\
\hline $\begin{array}{l}\text { Distal } \\
\text { anastomosis site }\end{array}$ & & & 0.146 \\
\hline Zone 0 & 7 & 2 & \\
\hline Zone 1 & 6 & 5 & \\
\hline Zone 2 & 14 & 19 & \\
\hline Zone 3 & 8 & 3 & \\
\hline $\begin{array}{l}\text { Diameter of FET } \\
\text { Mean } \pm \text { SD }\end{array}$ & $29.1 \pm 3.2$ & $29.8 \pm 2.8$ & 0.375 \\
\hline $\begin{array}{l}\text { Length of FET } \\
\text { Mean } \pm S D\end{array}$ & $8.7 \pm 2.0$ & $9.0 \pm 2.3$ & 0.530 \\
\hline $\begin{array}{l}\text { Concomitant } \\
\text { surgery } \\
n(\%)\end{array}$ & $13(37.1)$ & $3(10.3)$ & 0.014 \\
\hline $\begin{array}{l}\text { Coronary artery } \\
\text { bypass grafting } \\
n(\%)\end{array}$ & $6(17.1)$ & $3(10.3)$ & 0.436 \\
\hline $\begin{array}{l}\text { Aortic valve } \\
\text { replacement } \\
n(\%)\end{array}$ & $3(8.6)$ & $0(0)$ & 0.106 \\
\hline $\begin{array}{l}\text { David operation } \\
n(\%)\end{array}$ & $4(11.4)$ & $0(0)$ & 0.060 \\
\hline $\begin{array}{l}\text { Operative } \\
\text { time (min) } \\
\text { Mean } \pm S D\end{array}$ & $409.4 \pm 87.8$ & $468.6 \pm 129.6$ & 0.034 \\
\hline CPB time (min) & $177.7 \pm 50.4$ & $222.9 \pm 96.7$ & 0.019 \\
\hline $\begin{array}{l}\text { Aortic clamping } \\
\text { time (min) } \\
\text { Mean } \pm S D\end{array}$ & $115.3 \pm 55.7$ & $114.2 \pm 35.0$ & 0.924 \\
\hline $\begin{array}{l}\text { HCA time }(\min ) \\
\text { Mean } \pm S D\end{array}$ & $39.5 \pm 13.4$ & $54.5 \pm 18.5$ & 0.001 \\
\hline $\begin{array}{l}\text { Minimal rectal } \\
\text { temperature }\left({ }^{\circ} \mathrm{C}\right) \\
\text { Mean } \pm \mathrm{SD}\end{array}$ & $26.1 \pm 1.3$ & $26.4 \pm 1.7$ & 0.370 \\
\hline $\begin{array}{l}\text { Intraoperative } \\
\text { bleeding } \\
\text { amount }(\mathrm{mL}) \\
\text { Mean } \pm S D\end{array}$ & $4,854 \pm 3,187$ & $5,890 \pm 4,399$ & 0.295 \\
\hline
\end{tabular}

Abbreviations: CPB, cardiopulmonary bypass; FET, frozen elephant trunk; Group A, group of attending surgeons; Group T, group of trainees; HCA, hypothermic circulatory arrest; SD, standard deviation.

than group T (4 vs. $0, p=0.060$ ). Reflecting our operator selection process, there was also tendency of higher risk, when calculated by Japan score, in group A than in group T; but this did not reach statistical significance $(9.1 \pm 7.5$ vs. $6.9 \pm 5.3, p=0.170)$.

Intraoperative parameters are listed in - Table 2. Diameter and length of used FET did not differ between groups. Zone-3 anastomosis was done in eight patients in group A, whereas there was only three patients in group $\mathrm{T}$ because patients with expected deeper distal anastomosis were assigned to attending surgeons. Operative time ( $409.4 \pm 87.8$ vs. $468.6 \pm 129.6$ minutes, $p=0.034$ ), СРВ time $(177.7 \pm 50.4$ vs. $222.9 \pm 596.7$ minutes, $p=0.019)$, and HCA time $(39.5 \pm 13.4$ vs. $54.5 \pm 18.5$ minutes,
Table 3 Postoperative complications

\begin{tabular}{|l|l|l|l|}
\hline & $\begin{array}{l}\text { Group A } \\
(\boldsymbol{n}=35)\end{array}$ & $\begin{array}{l}\text { Group T } \\
(\boldsymbol{n}=\mathbf{2 9})\end{array}$ & $p$-Value \\
\hline $\begin{array}{l}30 \text { days mortality } \\
n(\%)\end{array}$ & $1(2.9)$ & $1(3.4)$ & 0.892 \\
\hline $\begin{array}{l}\text { Hospital mortality } \\
n \text { (\%) }\end{array}$ & $2(5.7)$ & $1(3.4)$ & 0.669 \\
\hline $\begin{array}{l}\text { Rethoracotomy } \\
\text { for bleeding } \\
n(\%)\end{array}$ & $1(2.9)$ & $0(0)$ & 0.359 \\
\hline $\begin{array}{l}\text { Mediastinitis } \\
n(\%)\end{array}$ & $0(0)$ & $1(3.4)$ & 0.268 \\
\hline $\begin{array}{l}\text { Temporary } \\
\text { neurological deficit } \\
n \text { (\%) }\end{array}$ & $1(2.9)$ & $0(0)$ & 0.359 \\
\hline $\begin{array}{l}\text { Stroke } \\
n(\%)\end{array}$ & $3(8.6)$ & $2(6.9)$ & 0.804 \\
\hline $\begin{array}{l}\text { Paraplegia } \\
n(\%)\end{array}$ & $2(5.7)$ & $0(0)$ & 0.191 \\
\hline $\begin{array}{l}\text { Acute kidney injury } \\
n(\%)\end{array}$ & $6(17.1)$ & $1(3.4)$ & 0.081 \\
\hline $\begin{array}{l}\text { Postoperative } \\
\text { maximal serum } \\
\text { creatinine (mg/dL) } \\
\text { Mean } \pm \text { SD }\end{array}$ & $1.59 \pm 1.29$ & $1.36 \pm 0.87$ & 0.392 \\
\hline
\end{tabular}

Abbreviations: Group A, group of attending surgeons; Group T, group of trainees; SD, standard deviation.

$p=0.001$ ) were significantly shorter in group A than in group $\mathrm{T}$, but aortic clamping time did not differ between the two groups ( $115.3 \pm 55.7$ vs. $114.2 \pm 35.0$ minutes, $p=0.924$ ) because the rate of concomitant surgery was higher in group A (37.1 vs. $10.3 \%, p=0.014$ ).

Postoperative results are demonstrated in -Table 3 . Although operation time was longer in group $\mathrm{T}$, there were no significant differences in postoperative results between the groups. Two patients died within 30 days postoperation. One patient in group A having AADA died on postoperative day 17 due to acute exacerbation of chronic liver dysfunction (ChildPugh classification: $B$ ) based on liver cirrhosis. The other patient also had AADA, but in group $T$, had suffered from severe stroke and multiorgan failure and died on postoperative day 29. There was one more in-hospital death. A patient in group A having aneurysm and very shaggy aorta suffered from severe stroke and paraplegia died on postoperative day 42 due to multiorgan failure. Regarding paraplegia, there were two patients with the complication. One of these patients is described above. The other patient is also from group $A$ and had AADA; the patient had no paraplegia immediately after operation, but after suffering severe sepsis on postoperative day 5 developed paraplegia. Regarding stroke, there were five patients with the complication. Two patients have already been mentioned above, one patient from group A with aneurysm had a disabling stroke, and two patients had minor strokes and made complete recoveries.

As a subanalysis, risk factors for major adverse events were analyzed. Because only two patients died (one in group A, and 
one in group T), in-hospital mortality $(n=3)+$ major complications including rethoracotomy $(n=1)$, mediastinitis $(n=1)$, stroke $(n=5)$, paraplegia $(n=2)$, and postoperative acute kidney injury $(n=7)$ were all defined as a composite adverse event. Seven patients were identified to have in-hospital mortality + major complications because five patients had multiple adverse events. The results of this subanalysis are presented in - Table 4. Significant factors for in-hospital mortality + complications were chronic kidney injury $(p=0.020)$, preoperative value of serum creatinine $(p=0.018)$, JapanSCORE (0.007), and aortic clamping time $(p=0.035)$. Experience level of the operator did not influence in-hospital mortality + major complications $(p=0.346)$.

To identify independent predictive factors for in-hospital mortality + complications, factors with $p$-value less than 0.2 and experience of the operator, which is the main focus of this study, were analyzed with multivariate regression analysis and the result is presented in - Table 5. JapanSCORE and operation time were independent predictors for in-hospital mortality + major complications but experience of the operator was not identified as an independent factor.

Mean follow-up period was $1,022 \pm 352$ days. Six patients in group $\mathrm{A}$ and two patients in group $\mathrm{T}$ died during the followup period; Causes of death were postoperative multiorgan failure in two patients, pneumonia in two patients, rupture of the descending aorta in one patient, and suicide in one patient in group $A$ and postoperative stroke in one patient and thyroid cancer in one patient in group $\mathrm{T}$ (-Fig. 4A).

During follow-up, seven aortic events occurred. Enlargement of the aneurysm due to type Ib endoleak was observed in two patients, distal stent-graft induced new entry (dSINE) in three patients, narrowing of the true lumen presenting malperfusion of the lower body in one patient, and aortic rupture in one patient ( $\mathbf{- F i g . 4 B}$ ). The patient with aortic rupture died in another hospital. Autopsy imaging using CT scan revealed aortic rupture in the descending aorta, but further information could not be obtained. However, the other six patients (enlargement of aneurysm due to type Ib endoleak in two patients, narrowing of the true lumen in one patient and dSINE in three patients) were treated with additional TEVAR and have survived.

\section{Discussion}

In the present study, we were able to demonstrate that proximalized TAR using FET with extra-anatomical reconstruction of the left subclavian artery can be safely performed by trainees in selected patients.

\section{Educational Situation in Japan and Difference from Other Countries}

In the past, a cardiac surgeon would usually debut as a main operator on an atrial septal defect (ASD) case. Then she/he would go on to do many coronary artery bypass grafting (CABG) for ischemic heart disease cases, aortic valve replacement (AVR) for aortic valve regurgitation or stenosis, and mitral valve replacement for rheumatic mitral disease. ${ }^{9-12}$ Opportunities to operate on more complex cardiac surgeries
Table 4 Risk analysis for in-hospital mortality + major complications

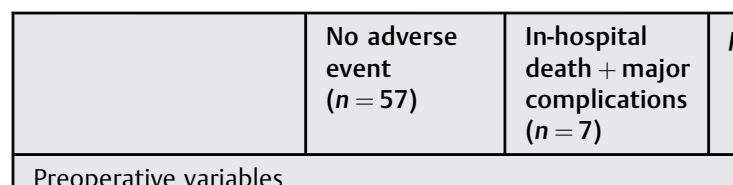

Preoperative variables

\begin{tabular}{|l|l|l|l|}
\hline $\begin{array}{l}\text { Age }(\mathrm{y}) \\
\text { Mean } \pm \text { SD }\end{array}$ & $71.1 \pm 10.5$ & $70.9 \pm 10.3$ & 0.963 \\
\hline $\begin{array}{l}\text { Male } \\
n(\%)\end{array}$ & $38(66.6)$ & $5(71.4)$ & 0.800 \\
\hline $\begin{array}{l}\text { Height }(\mathrm{cm}) \\
\text { Mean } \pm \text { SD }\end{array}$ & $160.3 \pm 9.9$ & $160.7 \pm 8.5$ & 0.911 \\
\hline $\begin{array}{l}\text { Weight }(\mathrm{kg}) \\
\text { Mean } \pm \text { SD }\end{array}$ & $62.6 \pm 19.9$ & $62.3 \pm 19.4$ & 0.964 \\
\hline
\end{tabular}

\begin{tabular}{|c|c|c|c|}
\hline $\begin{array}{l}\text { Body mass } \\
\text { index }\left(\mathrm{kg} / \mathrm{m}^{2}\right) \\
\quad \text { Mean } \pm \mathrm{SD}\end{array}$ & $24.1 \pm 5.0$ & $23.9 \pm 6.2$ & 0.937 \\
\hline
\end{tabular}

\begin{tabular}{|c|c|c|c|}
\hline $\begin{array}{l}\text { Hypertension } \\
n(\%)\end{array}$ & $47(82.4)$ & $6(85.7)$ & 0.829 \\
\hline $\begin{array}{l}\text { Diabetes mellitus } \\
n(\%)\end{array}$ & $10(17.5)$ & $2(28.5)$ & 0.481 \\
\hline $\begin{array}{l}\text { Hyperlipidemia } \\
n(\%)\end{array}$ & $24(42.1)$ & $1(14.2)$ & 0.155 \\
\hline
\end{tabular}

\begin{tabular}{|c|c|c|c|}
\hline $\begin{array}{l}\text { Current smoker } \\
n(\%)\end{array}$ & $16(28.0)$ & $4(57.1)$ & 0.117 \\
\hline $\begin{array}{l}\text { Chronic kidney } \\
\text { disease } \\
n(\%)\end{array}$ & $6(10.5)$ & $3(42.8)$ & 0.020 \\
\hline $\begin{array}{l}\text { Serum creatinine } \\
(\mathrm{mg} / \mathrm{dL}) \\
\quad \text { Mean } \pm \mathrm{SD}\end{array}$ & $0.97 \pm 0.53$ & $1.49 \pm 0.55$ & 0.018 \\
\hline $\begin{array}{l}\text { Hemodialysis } \\
n(\%)\end{array}$ & $1(1.7)$ & $0(0)$ & 0.724 \\
\hline $\begin{array}{l}\text { Previous PCl } \\
n(\%)\end{array}$ & $5(8.7)$ & $0(0)$ & 0.414 \\
\hline $\begin{array}{l}\text { Acute aortic } \\
\text { dissection type A } \\
\quad n(\%)\end{array}$ & $16(28.0)$ & $3(42.8)$ & 0.419 \\
\hline $\begin{array}{l}\text { Reoperative case } \\
n(\%)\end{array}$ & $4(7.0)$ & $0(0)$ & 0.469 \\
\hline $\begin{array}{l}\text { Japan score } \\
\text { Mean } \pm S D\end{array}$ & $7.3 \pm 6.1$ & $14.4 \pm 8.1$ & 0.007 \\
\hline
\end{tabular}

\begin{tabular}{|c|c|c|c|}
\hline \multicolumn{4}{|l|}{ Operative variables } \\
\hline $\begin{array}{l}\text { Operated by trainee } \\
n(\%)\end{array}$ & $27(47.3)$ & $2(28.5)$ & 0.346 \\
\hline $\begin{array}{l}\text { Zone- } 0 \text { anastomosis } \\
\quad n(\%)\end{array}$ & $8(14.0)$ & $1(14.3)$ & \multirow[t]{4}{*}{0.862} \\
\hline $\begin{array}{l}\text { Zone- } 1 \text { anastomosis } \\
\quad n(\%)\end{array}$ & $9(15.7)$ & $2(28.5)$ & \\
\hline $\begin{array}{l}\text { Zone- } 2 \text { anastomosis } \\
\quad n(\%)\end{array}$ & $30(52.6)$ & $3(42.8)$ & \\
\hline $\begin{array}{l}\text { Zone-3 anastomosis } \\
n(\%)\end{array}$ & $10(17.5)$ & $1(14.3)$ & \\
\hline $\begin{array}{l}\text { Diameter of } \\
\text { FET }(\mathrm{mm}) \\
\quad \text { Mean } \pm \text { SD }\end{array}$ & $29.3 \pm 3.0$ & $30.0 \pm 3.2$ & 0.576 \\
\hline \multirow{2}{*}{$\begin{array}{l}\text { Length of FET }(\mathrm{cm}) \\
\text { Mean } \pm S D\end{array}$} & $8.6 \pm 2.1$ & $9.8 \pm 2.2$ & 0.171 \\
\hline & $13(22.8)$ & $3(42.8)$ & 0.248 \\
\hline
\end{tabular}


Table 4 (Continued)

\begin{tabular}{|c|c|c|c|}
\hline & $\begin{array}{l}\text { No adverse } \\
\text { event } \\
(n=57)\end{array}$ & $\begin{array}{l}\text { In-hospital } \\
\text { death + major } \\
\text { complications } \\
(n=7)\end{array}$ & $p$-Value \\
\hline $\begin{array}{l}\text { Concomitant } \\
\text { surgery } \\
n(\%)\end{array}$ & & & \\
\hline $\begin{array}{l}\text { Coronary artery } \\
\text { bypass grafting } \\
n(\%)\end{array}$ & $6(14.0)$ & $1(14.3)$ & 0.986 \\
\hline $\begin{array}{l}\text { Aortic valve } \\
\text { replacement } \\
n(\%)\end{array}$ & $2(3.5)$ & $1(14.3)$ & 0.203 \\
\hline $\begin{array}{l}\text { David operation } \\
n(\%)\end{array}$ & $3(5.3)$ & $1(14.3)$ & 0.352 \\
\hline $\begin{array}{l}\text { Operative } \\
\text { time }(\min ) \\
\quad \text { Mean } \pm S D\end{array}$ & $423.3 \pm 109.6$ & $541.3 \pm 69.4$ & 0.070 \\
\hline $\begin{array}{l}\text { CPB time (min) } \\
\text { Mean } \pm S D\end{array}$ & $193.1 \pm 76.2$ & $239.3 \pm 84.2$ & 0.140 \\
\hline $\begin{array}{l}\text { Aortic clamping } \\
\text { time }(\min ) \\
\quad \text { Mean } \pm S D\end{array}$ & $110.5 \pm 44.6$ & $150.0 \pm 55.7$ & 0.035 \\
\hline $\begin{array}{l}\text { HCA time (min) } \\
\text { Mean } \pm S D\end{array}$ & $45.1 \pm 16.6$ & $55.7 \pm 22.8$ & 0.132 \\
\hline $\begin{array}{l}\text { Minimal rectal } \\
\text { temperature }\left({ }^{\circ} \mathrm{C}\right) \\
\text { Mean } \pm \mathrm{SD}\end{array}$ & $26.2 \pm 1.5$ & $26.3 \pm 1.3$ & 0.789 \\
\hline $\begin{array}{l}\text { Intraoperative } \\
\text { bleeding } \\
\text { amount (mL) } \\
\text { Mean } \pm S D\end{array}$ & $5,149 \pm 3,799$ & $6,738 \pm 3,654$ & 0.299 \\
\hline
\end{tabular}

Abbreviations: CPB, cardiopulmonary bypass; FET, frozen elephant trunk; Group A, group of attending surgeons; Group T, group of trainees; HCA, hypothermic circulatory arrest; $\mathrm{PCl}$, percutaneous coronary intervention; SD, standard deviation.

Table 5 Multivariate predictors for in-hospital mortality + major complications

\begin{tabular}{|l|l|l|}
\hline & OR $(95 \% \mathrm{CI})$ & $p$-Value \\
\hline Japan score & $1.123(1.008-1.251)$ & 0.036 \\
\hline Operation time (min) & $1.009(1.001-1.017)$ & 0.027 \\
\hline
\end{tabular}

Abbreviations: $\mathrm{Cl}$, confidence interval; OR, odds ratio.

such as mitral valve repair for mitral valve regurgitation, and aortic surgeries were limited, and assigned to experienced surgeons. $^{13}$

With recent development in technologies, however, ASD is very often treated interventionally, and few patients are brought to the operating table. ${ }^{14}$ The few cases that are brought to the operating table are for minimally invasive cardiac surgery, which are not trainee oriented. ${ }^{15,16}$ The number of patients undergoing CABG is rapidly decreasing due to development of drug-eluting stents. ${ }^{17,18}$ The number of patients who would have otherwise undergone surgical AVR is decreasing because of the widespread of transcatheter aortic valve implantation. ${ }^{19}$ Rheumatic mitral valve disease is decreasing due to improvement in mediations. ${ }^{20}$ Thus, educational cases in the surgical field are being weeded out, and rapidly decreasing; this is in many ways fortunate for patients but very unfortunate for surgical trainees.

On the other hand, the number of aortic surgery is increasing, especially in Japan. ${ }^{18}$ If TAR could be performed safely by less experienced trainees, surgical education opportunities would reflourish, despite the decrease in simple CABG and valve operations. To the best of our knowledge, this is the first report demonstrating that TAR can be safely performed by trainees.

\section{Proximalized Total Arch Replacement}

The concept of proximalized TAR using FET with extraanatomical reconstruction of the left subclavian artery itself is not new. Koizumi et al reported a similar operation technique done on 30 patients with distal aortic arch aneurysm, with acceptable results (30-day mortality, 0\%; stroke, $10 \%$; and paraplegia, $3 \%$ ). ${ }^{6}$ Yamamoto et al reported zone-0 anastomosis TAR using FET for patients with AADA, where they also utilized extra-anatomical reconstruction of the left subclavian artery. ${ }^{21}$ The advantage of such proximalized TAR using FET with extra-anatomical reconstruction of the left subclavian artery is not only the merit of avoiding deep distal anastomosis but also avoiding in-situ reconstruction of the left subclavian artery. Pichlmaier et al reported a unique operative technique of bridging the end-to-end anastomoses between the graft branches and the supra-aortic vessels by self-expanding covered stents to reduce suturing time, avoid anastomotic bleeding, and improve vessel alignment to the hybrid graft. ${ }^{22}$ As they noted, reconstruction of supra-aortic vessels, especially the left subclavian artery is sometimes technically challenging due to the very deep surgical field and marginal vessel wall quality of the proximal part of the left subclavian artery. With the proximalized TAR technique, all anastomoses can be performed on healthy vessel walls in relatively safe position in cases of aneurysm, therefore it may be ideal for surgical education. On the other hand, in cases of AADA, anastomoses between the side branches of the graft and the native supra-aortic vessels are sometimes difficult even if the proximalized TAR technique is applied, therefore we selected only patients having nondissected supra-aortic vessels for trainees.

\section{Training Program of Aortic Surgery and Patient Selection for Trainee}

At our institute, a trainee begins aortic surgery with isolated replacement of the ascending aorta in cases of AADA or proximalized TAR in cases of aneurysm. Needless to say, such operations are performed under proper supervision by attending surgeons, and sometimes several stitches will be done by the supervising attending surgeon in difficult areas. In cases of elective TAR for aneurysm, the main operator was selected according to operative risks during our preoperative conferences, as described in the "Methods" section. We consider that TAR with zone-3 anastomosis and TAR for AADA are too difficult for trainees in the early stage, and such operations are done by attending surgeons or experienced trainees, as shown in our data. 


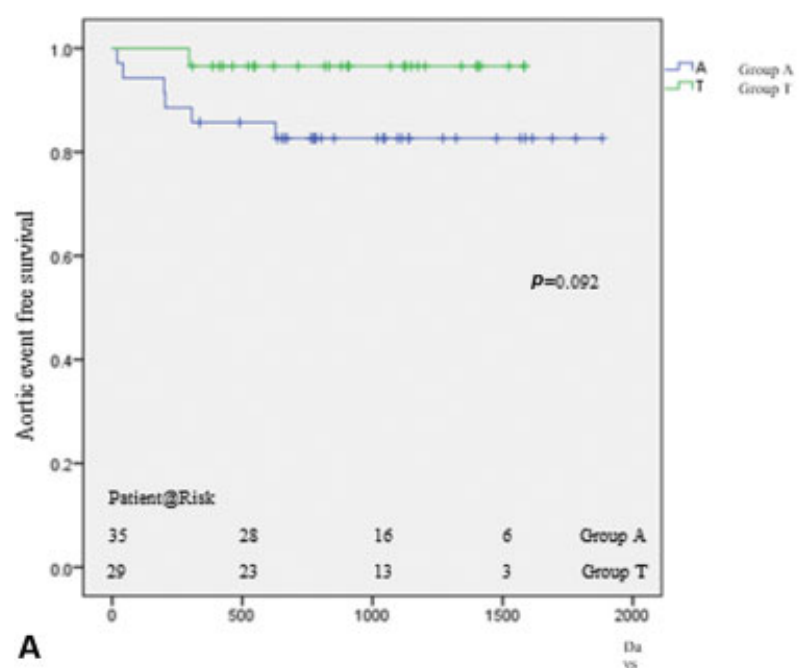

Fig. 4 (A) Survival rate. (B) Aortic event free rate.

\section{May Prolonged Time Factors Jeopardize the Safety of Patients?}

In the present study, operation time, CPB time, and aortic clamping time were significantly longer in group T. Furthermore, prolonged operation time was an independent predictor for in-hospital mortality + major complications. In general, prolonged operation time, $\mathrm{CPB}$ time, and aortic clamping time are strongly associated with worse outcome in cardiac surgery $^{23}$ and aortic surgery may be more sensitive to those time factors. Keeling et al demonstrated that prolonged operative time factors were significant predictors for adverse outcome in TAR with antegrade cerebral perfusion under moderate hypothermic circulatory arrest in an international database of 3,264 patients. ${ }^{3}$ Ghoreishi et al reported similar findings among patients with AADA in the society of thoracic surgeons database. ${ }^{24}$ On the other hand, there have been several reports reporting that cardiac surgery can be safely performed by trainee despite prolonged operative time factors if patient selection was correct and operations were performed under proper supervision of experienced attending surgeons. ${ }^{25,26}$ We agree with such previous studies because the experience of the operator did not influence in-hospital mortality + major complications in our study. The present study demonstrated that prolonged time factors by trainee in TAR is allowed without affecting patient safety if patient selection is correct and surgery is done under proper supervision.

\section{Potential Disadvantage of Frozen Elephant Trunk}

It is well known that the use of FET can increase the risk of paraplegia. ${ }^{27}$ In fact, two patients in the present series suffered from paraplegia, making the paraplegia rate in the entire cohort $3 \%$. However, one patient had very shaggy aorta and also suffered from systemic embolization resulting in stroke and ischemia of the lower extremities. It is possible that embolization of the intercostal arteries played a large role in the comorbid paraplegia. Moreover, in this particular operation, circulatory arrest time extended to a total of 78 minutes due to technical difficulties whereby rectal temperature at

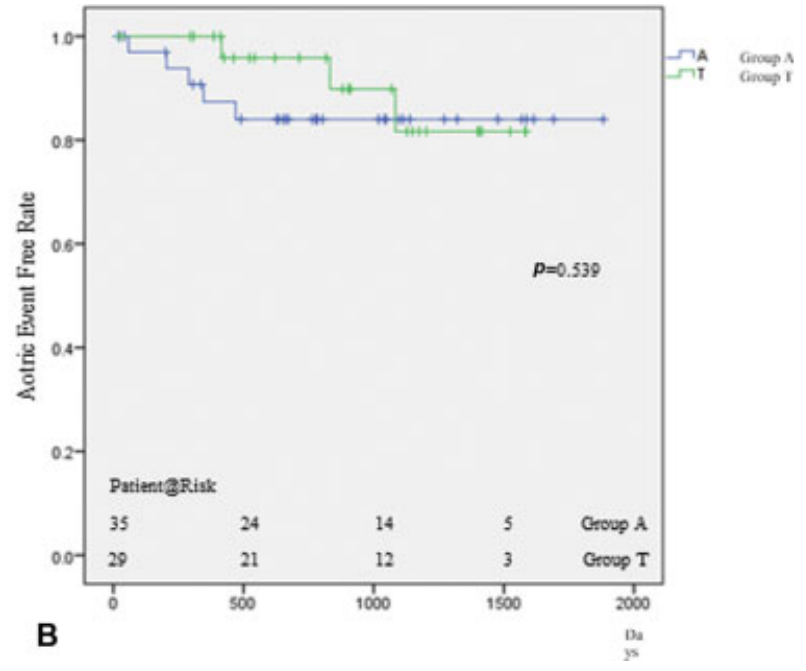

circulatory arrest was $26^{\circ} \mathrm{C}$. Hannover group reported that moderate hypothermic circulatory arrest time extending more than 60 minutes was strongly associated with the risk of paraplegia. ${ }^{28}$ Therefore, there are multiple factors that could have played into the occurrence of paraplegia in this patient, and cannot be solely pinned onto the use of FET.

\section{Study Limitation}

Some limitations need to be considered when interpreting the present results. First, the study was retrospective and could not exclude the biases inherently associated with this study type. Second, the sample size in the present study was very small. Nevertheless, since there have been no prior reports on training regiments in aortic surgery, the present study may carry worth and meaning for educational institutes.

\section{Conclusion}

The present study demonstrated that TAR can be safely performed by trainees, thus suggesting the possibility of TAR for educational operation. However, further accumulation of multicenter experiences is needed to validate our single-institutional experience and message.

Conflict of Interest

The authors declare that they have no conflict of interest.

\section{References}

1 Shelstad RC, Reeves JG, Yamanaka K, Reece TB. Total aortic arch replacement: advantages of varied techniques. Semin Cardiothorac Vasc Anesth 2016;20(04):307-313

2 Ikeno Y, Yokawa K, Matsueda T, et al. Long-term outcomes of total arch replacement using a 4-branched graft. J Thorac Cardiovasc Surg 2019;157(01):75-85.e3

3 Keeling WB, Tian DH, Leshnower BG, et al; IAASSG Investigators. Safety of moderate hypothermia with antegrade cerebral perfusion in total aortic arch replacement. Ann Thorac Surg 2018;105 (01):54-61 
4 Luehr M, Peterss S, Zierer A, et al. Aortic events and reoperations after elective arch surgery: incidence, surgical strategies and outcomes. Eur J Cardiothorac Surg 2018;53(03):519-524

5 Itagaki S, Chikwe J, Sun E, Chu D, Toyoda N, Egorova N. Impact of cerebral perfusion on outcomes of aortic surgery: STS adult cardiac database analysis. Ann Thorac Surg 2019;109(02): 428-435

6 Koizumi S, Nagasawa A, Koyama T. Total aortic arch replacement using frozen elephant trunk technique with J Graft Open Stent Graft for distal aortic arch aneurysm. Gen Thorac Cardiovasc Surg 2018;66(02):91-94

7 Yamane Y, Uchida N, Mochizuki S, Furukawa T, Yamada K. Earlyand mid-term aortic remodelling after the frozen elephant trunk technique for retrograde type $\mathrm{A}$ acute aortic dissection using the new Japanese J Graft open stent graft. Interact Cardiovasc Thorac Surg 2017;25(05):720-726

8 Motomura N, Miyata H, Tsukihara H, Takamoto S; Japan Cardiovascular Surgery Database Organization. Risk model of thoracic aortic surgery in 4707 cases from a nationwide single-race population through a web-based data entry system: the first report of 30-day and 30-day operative outcome risk models for thoracic aortic surgery. Circulation 2008;118(14):S153-S159

9 Noly PE, Rubens FD, Ouzounian M, et al. Cardiac surgery training in Canada: current state and future perspectives. J Thorac Cardiovasc Surg 2017;154(03):998-1005

10 Kogon B, Karamlou T, Baumgartner W, Merrill W, Backer C. Congenital cardiac surgery fellowship training: a status update. J Thorac Cardiovasc Surg 2016;151(06):1488-1495

11 Lin J, Reddy RM. Teaching, Mentorship, and Coaching in Surgical Education. Thorac Surg Clin 2019;29(03):311-320

12 Morse CR, Mathisen DJ. Educational challenges of the operating room. Thorac Surg Clin 2019;29(03):269-277

13 Komiya T. Introduction of cardiac surgery residency program at an earlier stage in surgical training. Gen Thorac Cardiovasc Surg 2013;61(12):694-698

14 O'Byrne ML, Levi DS. State-of-the-art atrial septal defect closure devices for congenital heart. Interv Cardiol Clin 2019;8(01):11-21

15 Okamoto K. Minimally invasive cardiac surgery in Japan: history and current status. Gen Thorac Cardiovasc Surg 2018;66(09):504-508

16 Ishikawa N, Watanabe G. Robot-assisted cardiac surgery. Ann Thorac Cardiovasc Surg 2015;21(04):322-328

17 Fernandez FG, Shahian DM, Kormos R, et al. The Society of Thoracic Surgeons National Database 2019 annual report. Ann Thorac Surg 2019;108(06):1625-1632
18 Shimizu H, Endo S, Natsugoe S, et al; Committee for Scientific Affairs, The Japanese Association for Thoracic Surgery. Thoracic and cardiovascular surgery in Japan in 2016 : Annual report by The Japanese Association for Thoracic Surgery. Gen Thorac Cardiovasc Surg 2019;67(04):377-411

19 Khan SU, Lone AN, Saleem MA, Kaluski E. Transcatheter vs surgical aortic-valve replacement in low- to intermediate-surgical-risk candidates: A meta-analysis and systematic review. Clin Cardiol 2017;40(11):974-981

20 Zühlke LJ, Beaton A, Engel ME, et al. Group A streptococcus, acute rheumatic fever and rheumatic heart disease: epidemiology and clinical considerations. Curr Treat Options Cardiovasc Med 2017; 19(02):15

21 Yamamoto H, Kadohama T, Yamaura G, et al. Total arch repair with frozen elephant trunk using the "zone 0 arch repair" strategy for type A acute aortic dissection. J Thorac Cardiovasc Surg 2019: S0022-5223(19)30360-5

22 Pichlmaier M, Luehr M, Rutkowski S, et al. Aortic arch hybrid repair: stent-bridging of the supra-aortic vessel anastomoses (SAVSTEB). Ann Thorac Surg 2017; 104(06):e463-e465

23 Iino K, Miyata H, Motomura N, et al. Prolonged cross-clamping during aortic valve replacement is an independent predictor of postoperative morbidity and mortality: analysis of the Japan Cardiovascular Surgery Database. Ann Thorac Surg 2017;103 (02):602-609

24 Ghoreishi M, Sundt TM, Cameron DE, et al. Factors associated with acute stroke after type A aortic dissection repair: an analysis of the Society of Thoracic Surgeons National Adult Cardiac Surgery Database. J Thorac Cardiovasc Surg 2019: S0022-5223(19)31213-9

25 Bloom JP, Heng E, Auchincloss HG, et al. Cardiac surgery trainees as "skin-to-skin" operating surgeons: midterm outcomes. Ann Thorac Surg 2019;108(01):262-267

26 Tolis G Jr., Spencer PJ, Bloom JP, et al. Teaching operative cardiac surgery in the era of increasing patient complexity: can it still be done? J Thorac Cardiovasc Surg 2018;155(05):2058-2065

27 Preventza O, Liao JL, Olive JK, et al. Neurologic complications after the frozen elephant trunk procedure: A meta-analysis of more than 3000 patients. J Thorac Cardiovasc Surg 2019:S0022-5223 (19)32242-1

28 Kamiya H, Hagl C, Kropivnitskaya I, et al. The safety of moderate hypothermic lower body circulatory arrest with selective cerebral perfusion: a propensity score analysis. J Thorac Cardiovasc Surg 2007;133(02):501-509 